\title{
PARASITIC HELMINTHES AMONG ANIMALS SLAUGHTERED AT DAKaflla PROVINCE ABATtOIRS
}

\author{
Abu-Elwafa, S. A. " and Al-Araby, M. A." \\ - Parasitology department. Faculty or Veterinary Medicine. Mansoura Universily.
}

\begin{abstract}
This siudy was ewoked to screen the helrninth parasttes among siaughtered animais in Dakahlia province through regular weekly visits to flue cities abattoirs including Moursoura, Betquas, Dekernes. Senbellawine anud Sherbeen. A total number of 2048 cattle, 648 bulfaloes and 133 sheep were examined at slaughtering for detection of helminth parasites. Inspection of sheep $\mathrm{CT}$ revealed Haemorthus spp. and Osterta gia spp. infections as abomasal uorms and Monlezia spp, and Avilellina spp.os iniestinal warms. Caucasses and liver inspection of slaughtered large animats reveated 2 genera of parasties (Setarta spp. in peritoneum and Fasciola spp. in liver). [rspection of GT of large ruminants yleided 4 genera of heininthes including Paramphistomum spp.. Carmyrius spp. Moniezia spp. and Taxacara uftulorum. Taxocara vitulorum was the gastrointestinal helminthes recouered from slaughtered buffalo culves less than 4 monits of age. Paramphistomum. T. vitulonum and Haemonchus spp. infections were predominat during Autumn, white that of camyrius and avitellina spp. was the highest during Whinter. Moreover. Spring had the highest uncidence of Fasclola. Ostertagta and Moniezka spp. of cattle. but that of sheep was increased durthy Summer. The previlence and seasonal dynamks of the detected parasites were studied vidependenty in each abattotr of the planned area.
\end{abstract}

Fey words: Helminth, rumtnants, slaughter.

$$
\begin{aligned}
& \text { اللمنص المريسى }
\end{aligned}
$$

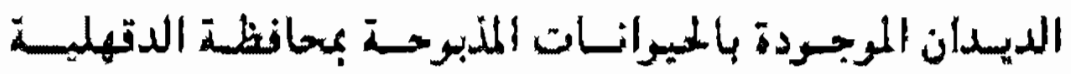

$$
\begin{aligned}
& \text { صلاح أحمد أبوالرنا. - مصطفى عبدالسلام العين. } \\
& \text { نسم الطنولهيات - كلية الطب اليبطرى - جامعة المصرية" }
\end{aligned}
$$

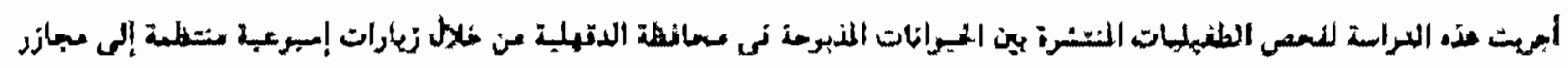




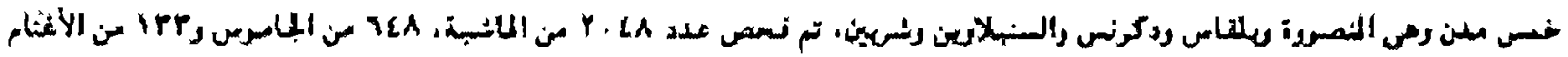

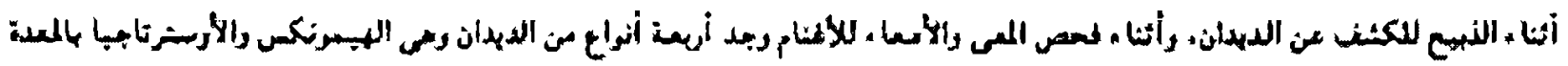

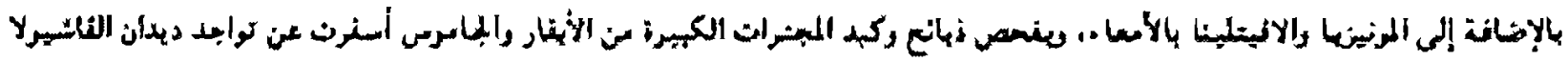

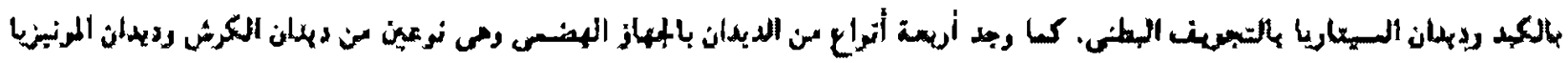

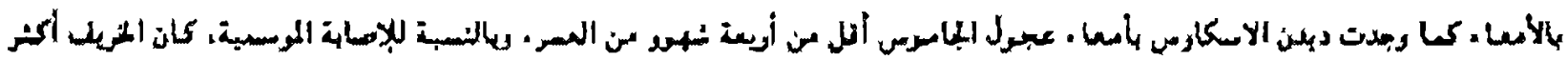

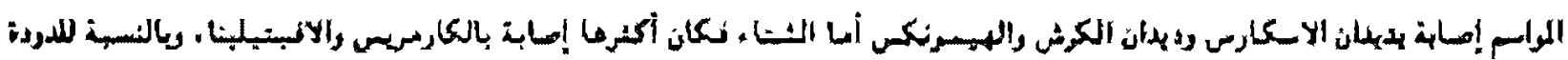

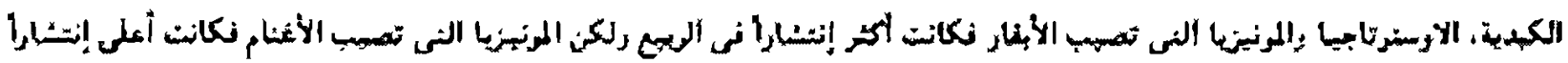

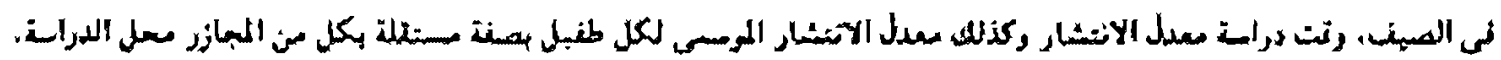

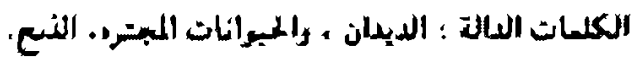

\section{INTRODUCTION}

Nowadays. the rapld increase of human population in Egypt necessitates a proportional Increase of feed substances. AnImal meat is considered the maln source of arimal protein. Nso, ralsing animals is an important mean to Increase the national income allover the world. In Egypt, bulfaloes. catte, sheep and goats represent the majortty of larm animals reared for meat and milk productlon. Such animals may suffer Irom parasille agents that may affect their lives and or production elther direetly or Indlrectly.

Direct adverse effects of parasittc constrain may include deaths. especlally in heavy infecLlans or untreated animals. Besides, direct losses during meat inspection at slaughtertng due to organ condemnation (as liver nbrosis In chronle [asclollasls]. Also, parasittsm may Indlrectly alfect animal productsulty and $/$ or breeding in dirferent ways as lowering fertlity. decreased weight gain as well as decreased milk and for meat production.

Moreover, parasites many exaggerate other microblal diseases as bacterdal pneumonla assoclater with lung worms infection. or carry other pathogens whlte wandering in Ulssues as Clostridlum noyyll, carrled by migrating forms of Fasciola spp. to sheep liver, the primary cause of sudden death in sheep lasclollasis. due to the massive invasion of liver parenchy. ma with both organisms.

Therefore, this study was carried out to screen the parasillc helminthes among andmals slaughtered at Dakahlia Province abattoirs. hopplng to help the planning of surtable control strategles needed for eradication of the persistent parasites, to obtain the maxl. mum benefits proposed from animal producUlon.

\section{MATERTAL AND METHODS}

Regular weekly vsits were submitted to main abattolrs of 5 clues Including Mansoura. Belquas. Dekernes, Senbellawine and Sherbeen during the period extended from september 2005 to the end of August 2006. A to. tal number of 2048 caltle, 648 buffaloes and 133 sheep were examined at slaughtening for

Manspura, Vet. Med. $J$.

Vol. X. Mo. 1. 2008 
detection of paraisituc helmlnthes. Examination of slaughtered animals had achieved in 2 ways:-

A During meat Inspection, the wholc carcacses were ayatematlcally examlned as follow:*

1. Lungs were examined by making inclslons through lung tlasue and large and small bronchl and bronchloles for detecuon of lung worms.

2. Luers were aiso examined by palpation and performing several incisions In liver parenchyma and blle ducts for detection of llver nukes.

3. Peritoneal cavities of slaughtered anlmals were, also Inspected for recovery of worms and / or cysts.

4. The obtalned gastrointestinal tracls were examined for gastrointestinal helminthes:

a) Rumen and reticulum were evacuated from Ingesta and inspecled for detec. tuon of rumen flukes.

b) Abomasum was Incised longitudinatly. cleared from contents and careful examination was pald to the aboma. sal wall for deteculon of stomach yorms. Also, wall scrapings were per. formed and collected in a sinall eontalner for laboratory examination.

c) Small and large Intestines were separately opened and examined grossly for adult heiminthes. Then, each part was opened and scrapings were transferred tnto a small contalner for laboratory examination.

d) Materlal obtalned from the atrove menuoncd inspectlons were moved to Parasitulogy department. Faculty or Vetertnary Mediclne. Marsoura University for laboratory examination.

B. Laboratory examinatlon and permanent preparation of the revealed parastea:

1. Scrapings taken from abomasum and intestlnes were left to sedjment for 30 ininutes, aiter which. the sediment was examined using binocular dissecting microscope and the detectcd parasiles were pteked up and put in a petridish containing tap water.

2. For washing and relaxation. the revealed worms were washed in lap water to rcsnove any adhering debris or mucous. kept in a little anount of water in a refrgerator elthcr for lew hours or overnight to be died in a relaxed eondition.

3. The revealed trematode fukes were com. pressed between two glass slldes, nxed In 10\% formaldehyde solution for at leasl 24 hours.

- The compressed worms were then washed in water lo get nde of formal. in remrants and stalned overnight in acetic acld alum carmine stain. Then, wastred In tap water, to remove the excess of stain.

- Differentiauon, when needed, was earrled out in aeid - alcohol (70\% elhyl alcohol $+4 \% \mathrm{HCl}$ ) untul reaching the proper staining degree.

- Then. the stalned worms were dehy- 
drated in ascending grades of ethanol. passed in xylene and finaliy mounted in Canada balsam.

4. Cestode helminthes uncre processed as trematode ones. but a special attention was given to scolices and mature and gravid segments.

5. The recovered nematode worms were plcked up. cleared in lactophenol solutuon and mounted in polywinyl alcohol. Also. rast green or light green stalns were sometlmes used for making coloured preparations by adding few crystals of the staln while elearing in factophenol.

6. Photos were taken by digital camera (Fuji A340 Aneplx 4.0 million plxels) and computertzed using ACDree-verslon 6.0.

\section{RESULTS \& DISCUSSION}

A total number of 2696 large ruminants and 133 small rumlnants (shcep) were invest1gated in slaughtering houses of five centers belonging to Dakahlla provtnce. Namely, Man. soura (2282 large rumlnants and 133 small ruminants): Belquas (126 large ruminants): Senbellawine (106 large rumlnants): Dekernes 1114 large rumlnants) and Sherbeen (68 lange ruminants).

Regarding helminth parasites of sheep staughtered at Mansoura abattoir, GIT inspection revealed Haemonchus spp, and Ostertagla spp. Infections as abomasal worns and Montezla spp. and Avtellna spp.as Intesunal worms. Examtnation of abomasums revealcd 35.71\% Haemonchus Infectlon efther single or mlxed with Ostertagia infextion $(11.22 \% 6)$. Examination of small intesune reveated $1.67 \%$ Monlezia inlection and 6.67\% infection with Avitellina: Table (1).

Concerning the seasonal nuctuation of the revealed sheep helminthes, Haemonchus spp. showed its bigher Incldence during Autumn (46.4\%) and Winter (38.1\%) then. declined during Spring (25\%) and Summer (29.7\%). Ostertagla spp. reached its highest level in Spring and Autumn to be 16.746 and 14.3\%6 respectuvely. The lowest Incldence was recordcd In Winter and Summer to be $9.5 \%$ and B. $1 \%$ respectively. On the other hand Monlezla infectlon was recorded only duning Summer (5.6\%), while completely disappeared durIng other seasons. Awltellina infectlon reached Its maxmum during Winter (12.5\%) and Summer $[11.1 \%)$. decreased in Autumn (3. \%\%). while disappeared in Spring season: Table (1).

Carcasses and iver Inspection of slaughtered large anisnals revealed the infection with 2 genera of parasttes (Setarla spp. in pertioneum and Fasclola spp. In llven. In this regard. Setarla spp. was only recovered from peritoneum of large animals slaughtered in Mansoura abattotr with a prevalence rate 10.08 \%). Meanwtile, Fastola spp. was deteeted In 1.03\% of examined animals. Senbeliaine had the highest prevalence $\{2.83$ of followed by Sherbeen (1.47 \%6). Mansoura (1\%) and Dekeines $(0.8896)$ while animals slaughtered in Belquas abattoir were free from Fasclola in. rectlon: Table (2).

Paramphistomum spp., Carnyrius spp.. Monlezia spp. and Toxocara vitulorum were 
the gastrointesunal helminthes recovcred from slaughtered large ruminants. Param. phistomum spp. infectuon recorded a total in. fectuon rate of $47.13 \%$, where the highest Incldence was in Dekerres (63.89\%). Tollowed by Senbellwalne (46.88\%), Mansoura (46.44\%). Sherbeen (43.75\%) and nnally Belquas $(41,18 \%)$. Carrnyrlus infection was only recorded from animals slaughtered al Mansoura abattois (1.43\%(6): Table (2).

Monlezia spp. was detected in 7.36\% of exarmined small Intestine, of slaughtered large ruminants In Dakahlla Prownce. The highest prevalence was recorded in Dekernes (10.53\%) followed by Senbelifialne (9.09\%) and Mansoura (7.99\%), while, animals slaughtered at Sherbeen and Belquas were found free from Monfezta infection, Toxocara vitulorum was only recorded from buftalo calves (under 4 months of age) slaughtered at Mansoura abattoir (47.9\%): Table (2).

Regarding the seasonal dymamics of the recorded parasites among the live centers in large rumlnants. Fasciola spp. recorded its highest incldence during Spring (1.6\%) followed by Winter (1.3196). Summer (1.18\%) and Anally Autumn (0.52\%). The seasonal dy. namics of the revealed parasites showed some differences among the investlgated abattolis. coneeming Fasclola spp. the lowest prevalence in Mansoura was detected In Autumn and Summer to be $(0.63 \%)$ and $(0.97 \%)$ respectuvely. whlle higher prevalence was detected during Spring and Winter to be $11.6 \%$ and $1.45 \%$ respectively). In Senbelliwalne center. Fasciola spp. was detected durng surnmer and winter 6.2546 and $2.44 \%$ respectlvely). In Dekernes and Sherbeen abattolrs, the same parasite was only detected in summer season $(5.27 \%$ and $6.25 \%$ respectively). Table (3).

With speclal reference to the seasmal dynamics of numen flukes of large numinants. Paramphistomum spp. reached Its peak in Autumn months (54.5\%), followed by Summer and Winter $(46.3 \%$ and 44.696$)$ while its minimal incidence was detected in spring (38.598). In Mansoura abattolr, it was found that Paramphistomum infecton increased durng Summer season (46.1\%) loward its maxlmum incidence during Autumn (54.9\%), while sllghtly deereased during Winter (43.3\%) and Spring (34.2\%). In Belquas Paramphistormum infection predominated duing Spring and Summer (50\% / each), while decreased in Au tumn (41.796) toward Winter (3096). In Senbellwalne. Paramphistomum revealed from nuInen and reticulum during Autumn (60\%3), Sumber $(50 \%)$ and winter $(47.1 \%)$ but not in Spring season. In Dekernes abaltotr, exarnmation of gastrointestinal bract of large ruminants revealed Paramphistomum infection driring Winter (71.4\%), Spring (66.7\%). Au. umn (64.396) and Summer (5096). Lastly. cattle slaughtered at Sherbeen abattols showed infection rate of (42.996) in Winter, reached its maximum in Spring (66.7\%6), while equal lowest Incldences were recorded during Summer and Autumn seasons (33.3\% / cach). Table (4).

On the other hand. Carmyrtus Infection reached its maximum in winter season (5\%) and sharply decreased in Spring (1.3\%) and Summer (1. 4\%) to be completely disappeared in Autumn season. Toxocara vitulorum (in buffalo calves below 4 months of agel reached 
Its peak during hulumn (60.3\%). whlle it was moderate in Winter $(47,7 \%)$ and summer (46.4\%) whlle Spring had the lowest prevalence $(23,196)$. Table (5).

With regard to Intestunal parasites of the same animals. Summer season had the highest prevalencc of Monlezia spp. (10.2\%), rollowed by Spring (7.6\%), Winter (5.6\%) and Autumn (5.3\%). In Mansoura abattolr. Monlezla Infection was the highest during Summer (9.8\%) and Whiter (8.5\%). followed by Spring (7.2\%) and Autumn (6.3\%). In Senbellwalne and Dekernes abattoirs. Monlezla Infection was only detected during summer season $(16.7 \%$ and $33.3 \%$ respectively). Table (6).

In the current study, 2 genera of abnmasal nematodes were reeorded in sheep; Haemonebus spp. and Osteragla spp. Hernonchus spp. showed higher Incldence (35.1\%) than Ostertagia spp. (11.22\%). The obtalned results was colnclded with El- Axaxy, 1990 in Sharkia and El-Axaxy, 1995 in Saudi Arahla but disagreed with Cabaret, 198 in Morocco. Moreover, 2 genera of intestinal helminthes were recorded: Moniezla spp. and Avitellina spp. the oblalned results were on contrary with Aydenzox and Yiz, 2003 in Turkey who reeorded a higher incidence of Monlezla spp. (3.9896) and a lower one for Avitellina spp. (0.86\%). These diflerences inay be due to different ecological or managernental faetors.

Dealing with the seasonal dynamlcs of the revealed sheep parasites; Haemonchus spp. and Ostertagla app. showed nearly simllar fluctuatlons (tncreased in Autumn and decreased in Summer]. The aehieved results were in agreement with Cabarek, 1984 in
Morocco , but dlsagreed with Reld and Asmour, 1075 who lound that the incldence was decreased in Auturnn and early Winter. Monlezia spp. In the current study was revealed only during Summer. This result was disagreed with Belem ot al; 2001 who menUoned that the incidence was Increased during the ralny seasons.

In the present study, the incidence of Fasclola spp in slaughtered large ruminants was considerably low (1.03\%). The achieved re. sults were agreed with Baldoek and Arthur. 1985 in Austrlala (1.1\%) but much lower than that obtalned by E1-Shazley ef al; 2002 in Dakahifa (12.31\%), and Prukenyt and Mukaz. atirva, 2004 In Ethiopla $(37,1 \%)$. The lower incidence of tasclollasls nowadays may be attributed to the application of covered drainage system Ior Irngation of agnicultural lands whileh declines the Intensity of snail intemediate host spread, and the repeated use of lascloliclde drugs. On the other hand Setarka spp. was revealed only from 0.08 of slaugh tered large ruminants, this very low Incdence was nearly slmflar to that recorded by RehbeIn et al; 1096 in Germany $(0.00 \%$ ).

Conceming the Incldence of ruminal flukes. the obtalned results of Paramphistomum spp. were near that obtained by Loe and Lee $1971(68.4 \%)$. Also. these results were In agrement with the range obtalned by Mage et al: 2002 In France (44.7\%) and Rangel-Rulz et al.. 200913.33 - $96.67 \%$ with average 39, $2 \% 1$.

The recorded prevalence of Monlezla spp In investigated abattoirs were around the results eoncluded by Lee and Lee, $197 \mathrm{1M}$ (8\%), while 
It was much higher than that delcetcd by Regassa et al; $2006(0.4 \%)$ and Aydenxoz and Mdz, 2003 in Turkey $10.22 \%$ for M. benede$\mathrm{ni}$ and $0.11 \%$ for $M$. expansa), Toxoeara vitulorum was recovered from $\mathbf{4 7 . 9 3 \%}$ of exam. Ined burfalo calves which was very higher than that reeorded by Akyot, 1893 in Turkey (5.1\%) and Regasea ot al.; 2006 in Eth!opla [2.8\%] in cattle calves. This marked difference may be attributed to specles suscepublity.

Regarding the seasonal fuetuation of the revealed heiminth parasites infecting slaughtered large ruminanats, Fasciola spp incldence In this Investigation was the highest in Spring and Winter, while the lowest was in Summer and Autumn. The achleved results were colncided with Khallaayoune and ElHarl, 1991, Ptukengi and Mukaratlrwa, 2004 who stated that the Incldence was In wet seasons more than the dry seasons. Also. Phlrt et al; 2005 recorded higher ineidence of fasclollasis in May and June ( Spring).

On the contrary of Fasciola spp. Param. phistormum spp. tnfcculon in slaughtered large rumInants showed a higher prevalence in Summer and Autumn. and a lower one in Spring and Winter. These results were conststent with that descrtbed by Rangel-Ruiz et al: 2003 in Mexico. Moreover. Moniezia spp. Inddence was Increased in Summer and Spring and a moderate incidence was observed in both Autumn and Winter. These results were disagreed with Belem et a): 2001. who stated that Monlezia spp. Infection was the highest in ralny seasons. Thls difference may be attributed to the tncidence of parastitle existence in the large numbers of animais exanlned during Summer than other seasons.

Generally. there were some varaboris in the prevalence and seasonal dynamics among the Irvestigated abattolrs even they have nearly the same inicroclimate. These diJTerences may be attributed to managemental fac lors (food type and repeated drug usage in treatment and prophylaxis of parasites) as weil as vicinlty of pastured animals lo branches of river and water channels. 


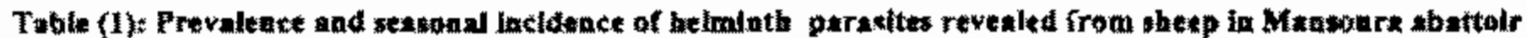

\begin{tabular}{|c|c|c|c|c|c|c|c|c|c|c|}
\hline \multirow{3}{*}{ Schatow } & \multicolumn{5}{|c|}{ Interitaes } & \multicolumn{5}{|c|}{ Stomach woras } \\
\hline & \multirow{2}{*}{$\begin{array}{c}\text { NO. } \\
\text { Ex. }\end{array}$} & \multicolumn{2}{|c|}{$\begin{array}{l}\text { Montisio } \\
\text { upe }\end{array}$} & \multicolumn{2}{|c|}{$\begin{array}{l}\text { Awneditina } \\
\text { seg }\end{array}$} & \multirow{2}{*}{$\begin{array}{l}\text { No* } \\
\text { Ex. }\end{array}$} & \multicolumn{2}{|c|}{$\begin{array}{c}\text { Hatmonchus } \\
\text { spa }\end{array}$} & \multicolumn{2}{|c|}{$\begin{array}{c}\text { Orfertagia } \\
\text { spen. }\end{array}$} \\
\hline & & $+v e$ & $\%$ & $+w_{0}$ & $\%$ & & $+\sqrt{4}$ & $\%$ & twe & $\%$ \\
\hline Antuma & 26 & $\ldots$ & 0.0 & 1 & 3.9 & 28 & 13 & 46.4 & 4 & 14.3 \\
\hline Wiater & 8 & 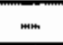 & 0,00 & 1 & 12.5 & 21 & 8 & 38.1 & 2 & 9.5 \\
\hline Spring & 8 & $* *$ & 0,0 & 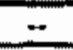 & 0.00 & 12 & 3 & 250 & 2 & 16.7 \\
\hline Strmuser & 18 & 1 & $\$ .6$ & 2 & 11.1 & 37 & 11 & 29.7 & 3 & 81 \\
\hline Total & 60 & 1 & 1.67 & 4 & 6.67 & 98 & 35 & 35.71 & 11 & 11.22 \\
\hline
\end{tabular}

Table(2): prevalence of helminth parasites in lone rumimats in Dakuhlie proviuce.

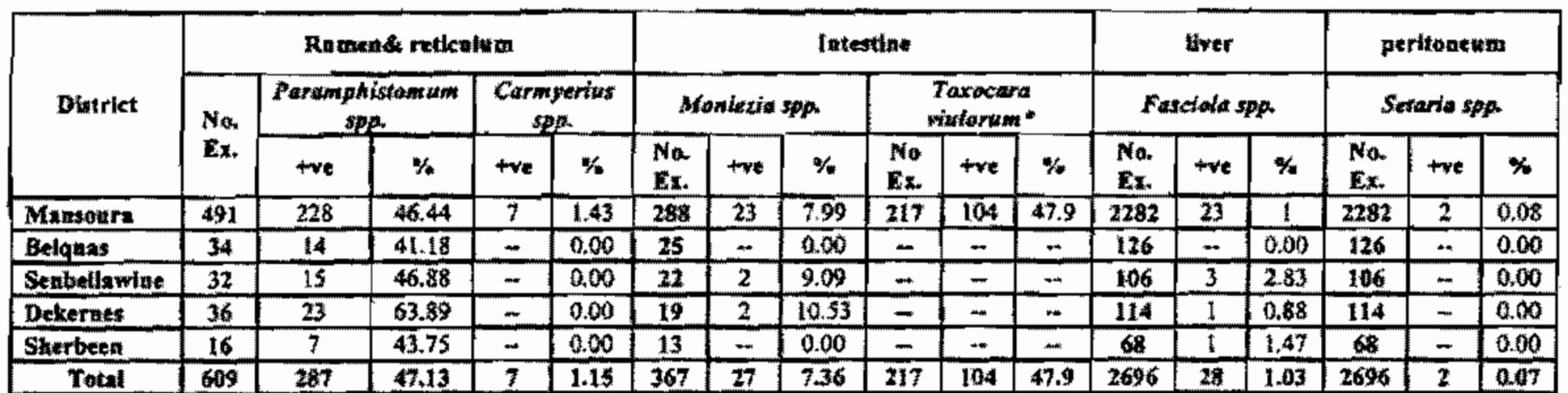

Tozockra vitnlonum revealed from buffalo calves below 4 months of age

Setaria species revenled from abdominal cavity of cattle 
Abu-Elwaja 5. A. and Al-Araby M, A.

Table (3): Seasonal dynamtes of Fastiola spa in Dukablls provisace.

\begin{tabular}{|c|c|c|c|c|}
\hline Senven Abuttoir & A atuman & Whaser & Spriag & Summer \\
\hline Mansoure & 0.63 & 1.43 & 1.6 & 0.87 \\
\hline Belvans & 0.00 & 0.00 & 0.00 & $0 \times 0$ \\
\hline 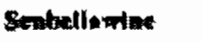 & Q.0A & 2.44 & $0.0 P$ & 6.25 \\
\hline Dalueriaes & 000 & 0.00 & 0.00 & 5.27 \\
\hline Sherbeth & 0.00 & 0.00 & 0.00 & 6.25 \\
\hline Tunil & 0.52 & 131 & 1.6 & 1.18 \\
\hline
\end{tabular}

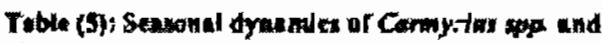

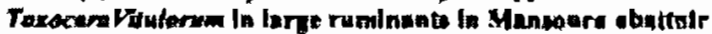

\begin{tabular}{|c|c|c|c|c|c|}
\hline Stason & Aolumn & Winter & Sprtag & Sommer & Towal \\
\hline $\begin{array}{l}\text { Cormprises } \\
\text { frogarins }\end{array}$ & 0.00 & 3 & 1.3 & I. 4 & 1,13 \\
\hline 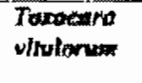 & 60.3 & AT.1 & $\dot{23.1}$ & 46.4 & 47.93 \\
\hline
\end{tabular}

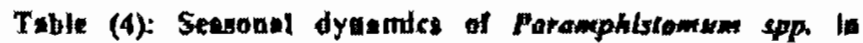
Dakabta province.

\begin{tabular}{|c|c|c|c|c|}
\hline Sestan Abuittole & Abtumn & Minfer & Sprten & Semmer \\
\hline Mansoner & 94.9 & 138 & 34.2 & 46.1 \\
\hline Betquas & 11.7 & 30 & 50 & 50 \\
\hline Sentellnmine & 60 & 47.1 & 0.00 & so \\
\hline Dethernte & 64.5 & $\pi .4$ & 66.7 & 30 \\
\hline Sberben & 31.3 & 429 & $\cos 7$ & 33.3 \\
\hline Toul & 545 & 446 & 34.5 & 463 \\
\hline
\end{tabular}

Table (6): Sensonal dyonmica of Afonirsio spa in Dakathe provinec.

\begin{tabular}{|c|c|c|c|c|}
\hline Seasen Abutislr & Autumn & Mnter & Spring & Sommar \\
\hline Menewore & 63 & 8.3 & 7.2 & 9.8 \\
\hline Edguno & 0.00 & 6.00 & 0.00 & 0.00 \\
\hline Sentuellnwlac & 0.00 & 0.00 & 0.00 & 16.7 \\
\hline Delluernet & 0.00 & $0 . \infty$ & 20 & 33.3 \\
\hline Sherben & 000 & 000 & 0.00 & 0.00 \\
\hline Tockl & 5 & 3.6 & 7.6 & 10.2 \\
\hline
\end{tabular}


Abu-Elwaja S. A. and Al-Araby M. A.

Parailite hedolathea rovealed from alaughtored antwals

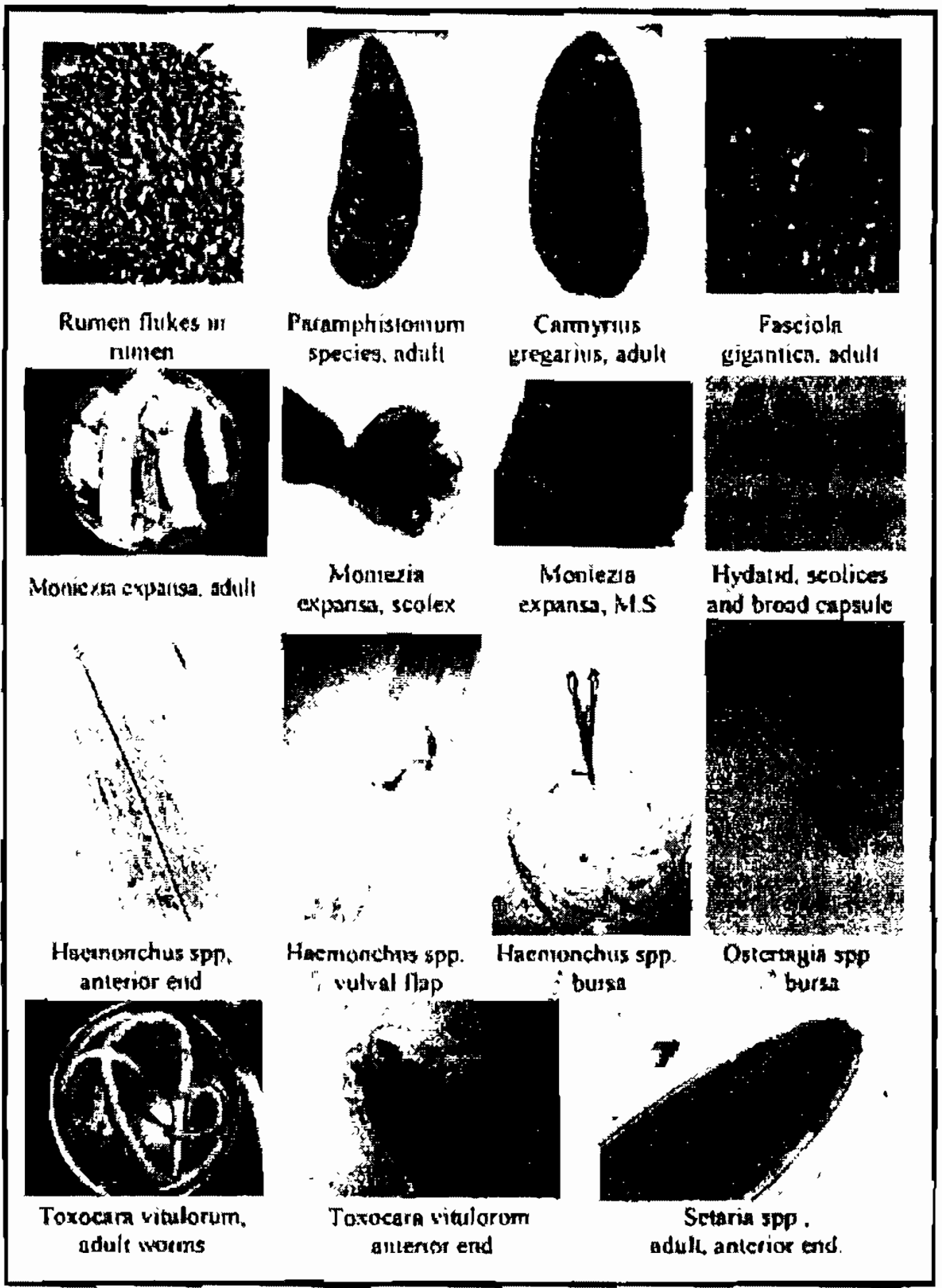

Mansoura, Vet. Med. $J$.

Vol. X, No. 1, 2008 


\section{REFERENCES}

Akyol, C. V. C. (1993) : Epldemtology of Toxocara vitulorum in cattle around Bursa. Turkey, J. Helminthol. 67(1):73-77,

Aydenzoz, M. and YIdz, (2003) : Prevalence of Anoplocephalidae species In shcep and cattle shughtered in KJrikkale. Turkey. Revue de Medictne Veterlnalre. 154(12):767. 771 .

Baldock, F. C. and Arthur, R. J. (1985): A survey of fascloliasls In beer callic killed al abattoirs in Southern Quecns Land. Aust. vet. J.,62(10); 324-326.

Belem. A. D. G.: guedraogo, O, P. And Bhesala, A. D. (2001) : Gastro irrestinal nematodes and ccstodes or catuc in Burkdna Fasso.Blotechnol. Agron. Soc.Enviton.,5 (1):17-21.

Cabert. J. (1984) : Seasomal changes in the abomasal nematodes of nalurally infected ewes in Moulay- Bovazza (Morocoo). Vet. Parasit.. 15(1): 47.56 .

El- Axazy, O. M. (1990) : Abscnce of hypoblosis in abomasal nematodes of sheep and goats in Egypt. Vet. Paraslt., 37(1); 55-60.

El- Axazy, O. M. (1998) ; Scasonal chang. es and inhibited development of the abomasal nemalodes of sheep and goats in Saudia Arabla, Vet. Parasit., 58(1-2): 91-98.

El-shazley, A. M.; El-Wafa, S, A.: Harldy. F. M.; Sollman, M.; wifaat, M. M. and MorBy. T. A. (2002) : Fasciollasis among Juve and
* slaughtered antmals in nine centers in Da kahlia Governorate. J Exypt. Soc. Parasth..32 $[1]: 47-57$.

Whallaayoune, $K$. and El-Harl, $M$. (1991) : Seasonal variations of Fasclola he patica infection in goats in the area of Haouz (Morocoo). Ann. Rech. Vet., 22(2): 219-226.

Lee, W, $C$ and Lee, $K$. W. (187 1$)$ : Eplzotlogical survey on infestation rate of helminths in koream natlve calte, Kisaengchun. ghak Chapthi.,9(2): 54-57.

Mage, $C_{r ;}$ bourgne, H.: Toulleu, J. M.a Rondelaud. D, and Dreyfuss. G. (2002) ; Fasciola hepatica and Paramphistomum doubneyl: Changes in prevalences of natural infections in cattie and Lymnaca truncatula from central France over the past 12 years.Vch. Res., 33: 439- 447.

Pfukenyl. D. M. and Mukaratirwa, S. (2004) : A retrospectlve study of the prevalence and seasonal variation of Fascola gigantica in cattle slaughtered in the major abattoirs of Zlmbabwe between 1990 and 1999. Ondcrstepoort J. Vet. Res, 7 I (3): 181-187.

PhIr, A. M.; Phlrl, I. K.; Siziya, S.; S1kasunge, C. S.; Chembensofu, M. and Monrad, J. (2005) : Seasonal pattern or bovine fasctolosis in the Kalue and Zambezl catch. ment arcas of Zambla, Vet. Parastt. 134(12): 87.92 .

Rangel-Ruiz, L. J.; Albores-Brhams, 8. T. and Gamosa- Agullar, J. (2003) : Seasonal trend of Paramphistomum cervl in Tabasco. Mcxico, Vet. Parasile, 116:217-222. 
Abu-Elwafa S. A. and Al Araby M. A.

Regassa, F.i, Sort, T،; Dhuguma, R. and Kros. Y. (2006) : Epldernioingy or gastroIntestinal parasites of rumbants in Westem Oronia, Ethlopla. Int. J.Appl. Res. Vet. Med. 4(1): $50-57$.

Rehbeln, 8.; Kollmannsberger, M.; Vls: oer. M. and Wlnter, R. (1896): Helminth burden of slaughtered sheep in Upper
- Bavaria. 1- Species spectium. infestation extent and infestation intensity. Berl. Munch. Tlerzl. Wochenschr, 109 (5): 161. 167.

Reld, J. F. and Armour, J. (1975) : Seasonal varlations in the gastro-inlestinal nematode populations of Scottlsh hill sheep. Res. Vet. SCl. 18(33):307-313. 